\title{
Media Influence on Political Parties in Albania
}

\author{
Anjeza Xhaferaj \\ European University of Tirana \\ Department of Applied Social Sciences
}

\begin{abstract}
This article investigates the role of television on the structure and organization of political parties in the post - communist Albania. The existing literature on political parties links the structure of mass parties with the written press, and the structure of electoral- professional and cartel parties with the increasing influence of television. The mass party is based on the principle of membership. Among many tasks that members had to carry out, the dissemination of party's declarations, statements, opinions and ideology, through the distribution of party press is one of the most important. The studies on political parties have observed the emergence of the catchall, electoral-professional and cartel party, in which the party leaders have substituted the membership organizational network with television, and thus minimized the role of intermediate party organs. In difference from their counterparts in Western Europe, in the new established democracies of post-communist countries, political parties were born in a period characterized by a modern and developed media which was accessible to everyone. Therefore, the immediate access to modern means of communication has distanced the parties from the society since the early phases of their inceptions, without giving them the opportunity and necessity to organize territorially. This article analysed the techniques that have used the Albanian political parties to communicate with their electorate, concluding that in the moment of their creation, television could not serve to the opposition parties as a means of information. That is why they had to rely heavily on the written press and their membership. The opening of some broadcasting channels, after 2000 , made possible the access on modern techniques of communication, leading to a minor role of the press and membership. As a result we could say that at the early phase of democratic process, the political parties in Albania shared features of the mass party with a strong territorial penetration, features that started to fade out when television gained a more prominent role in the organization of electoral campaigns by influencing thus a more contemporary western alike model of party organization.
\end{abstract}

Key Words: Political parties, Organizational structure, television, party press, leader's role

\section{INTRODUCTION}

The fall of communism in Europe was accompanied with several phenomena, among which the most important is the emergence of political parties. The appearance of political parties in the new democracies happened in a time when similar organization in the Western Europe had experienced radical changes in their structure and organization, changes that reflected the political, economic and social revolution that took place in the end of 19th and the beginning of the 20 th century.

With the fall of communism, was thought that the parties of Eastern and Central Europe would follow the path of western models in the context of democratization. Scholars also suggested that the post-communist parties would skip the earlier phases of development of political parties in Western Europe and would embrace the American "Catch- up- all" party model (Gross, 1992 in Webb \& White, pp.5). This was based on the argument that communism had levelled all social-economic differences and it was difficult if not impossible the creation of 
organizations that would organize and mobilize different social interest groups because such grous were inexistent (Bielasiak, 2002:189-90). Due to the weakness of cleavage structures, the partisan identities were also weak and because political parties had weak programmatic identities, such as in the case of Albania which falls under the category of patrimonial communism (Kitschelt et.al.,1999, pp. 42, 53-52), it was difficult for the electorate to identify itself with a political party and consequently for a political party to create an electorate of belonging (van Biezen, 2003, 35-37).

However, van Biezen identifies medias as another important factor which has influenced the structure and organization of post-communist political parties. Scholars (Panebianco, 1988; Katz \& Mair 1995) have already analyzed the role that mass media has played in changing the communication of political parties with their supporters and electorate. While, Duverger (1954) identified members as the necessary mechanism to transmit the message of the party leaders to the society, his successors have pointed out that in a context where mass communication became available, such mechanism of transmission was no longer necessary. By means of mass communication, the political leaders can now on communicate directly with the electorate without using the time-consuming mechanism of transmitting the message by means of branches and rank and file. Van Biezen argues that sequence development of events is important. Since mass communication became available to the political parties before they could organize in the form of a mass party, it hindered such process (2003, pp.41). Because, political leaders has instant access to the public because of the mass media, they do not invest, nor in time, neither in money, to organize a mass party.

Now, 25 years after the fall of communism, the literature on political parties in post communist parties is rich and academics have concluded that political parties in these countries exhibit similar features with their western counterparts; they are closer to the state than the society and orientated more towards the electorate and less towards members and organizational structures. What is the structure and organization of political parties in Albania? Despite several researches conducted on this topic, the literature is not rich and there is a lack of studies focused on their structure and organization. This article is an attempt to give an answer to this question and it starts with the premise that Albanian political parties did not have access to television at the moment of their creation. Therefore, they had to rely on the organizational structure of the mass party to transmit the party messages in the whole territory. To prove this it is important to see and analyse the amount of accessibility that political parties had on television at the moment of their inception as well as the percentage of coverage that the TV channel guaranteed.

\section{LITERATURE REVIEW: MEDIA AND POLITICAL PARTIES}

The media -party relationship has been powerful since the first days of their creation. Party leaders have immediately understood the importance of media, especially of written press, to transmit their political messages to the electorate. Michelis (2001[1917]) says that:

The press constitutes a potent instrument for the conquest, the preservation, and the consolidation of power on the part of the leaders. The press is the most suitable means of diffusing the fame of the individual leaders among the masses, for popularizing their names. The labor press ... is full of panegyrics concerning the personalities of the leaders, of references to their "disinterestedness and self-sacrificingness," to their "ardent idealism, conjoined with a vigorous force of conviction and with invincible tenacity," qualities which, we are told, have alone made it possible for them to create the great working class organizations. ... It is true that the press cannot exert the 
immediate influence which the popular propagandist exercises over his audience in public meetings, debates, and party congresses. In compensation for this defect, however, the circle of influence of the written word is far more extensive. The press can be used with effect to influence public opinion ... in order to gain or to retain the sympathy of the masses, and to enable them to keep the guidance of the movement in their own hands. The democratic press is also utilized by the leaders in order to make attacks (more or less masked) upon their adversaries; or to launch grave accusations against persons of note in the world of Politics or finance. These attacks may or may not be established upon a sufficient foundation of proof, but at any rate they serve to raise a dust storm (pg.83-84).

Therefore, the press served as a channel and an arena to transmit the party propaganda: the creation of the leader's cult, the presentation of the electoral campaign, the presentation of arguments for the elimination/ exclusion of party dissidents (read leader's opponents) and the attack against opposition parties. Having in mind that central party meetings, other branches and sub branches served for the same purpose, it looks like that media since its beginning turned into a parallel organization to the party structures. With regard to the political parties in consolidated democracies of Western Europe, the development of media and the increased accessibility of political parties to mass media, changed drastically the relationship between parties and society, especially due to the fall of importance of party organization in the communication of the party with the society (van Biezen, 2003: 40).

The classical mass-party of the Western Europe in the end of 19th and beginning of 20th century had to rely on the organizational network in order to be in contact with its membership and electoral zones. The organizational structure in terrain was needed for communicative and mobilizing motives. The press organs, controlled by the party, played an important role in informing society for the program and party aims, while the circulation and distribution of party press was managed by the members' activity. Apart from this, a large number of party members was indispensible for the so called "two-step flow of communication"( Lazerfeld et al., 1994) that means that each individual could be seen as an important source of information that produces " the snow-ball effect", according to which the lines of communication expand with the increasing number of supporters. The higher the number of party membership, the widest would be the spread of information and consequently its influence (van Biezen, pp.40-41). Kirscheimmer (1968), Pannebianco (1988) and Katz \& Mair (1995) noticed that instead of using the central organization from communicating with the electorate, now the party leaders communicate directly with the electorate, minimizing the role of intermediate party organs.

Political parties in the post-communist countries, in difference from their counterparts in the Western Europe, were born in times of a highly developed modern media and accessible for everyone. Now political parties can communicate their messages directly to the audience, militants and the electoral in general, through newspapers, radios and especially on television and as a consequence they do not need to recruit members to fulfil the communicative and mobilizing functions. The creation of an extensive organizational network in the field is no longer necessary.

Media accessibility has led towards a more personalized politics. The role of leaders is especially important in the context of a democratizing country and in the situation when many political parties are new, non- institutionalized and with a non-materialized identity that is not strong enough to stay above the leader's identity (Sartori, 1968). Pasquino (2001: 222) 
observs that in the South European context, politics tends to be personalized due to the fact that they are a product of the combination of two factors: the weak party organizations and a high TV influence. Said this, the image of the leader has taken a dominant role during campaign and parties are oriented towards a more centralizing and professionalizing structure, as Farell and Webb (2000: 123) agree in their analysis of political parties on industrialized countries (van Biezen, 2003: 41).

When we refer to modern techniques of organizing electoral campaigns, political parties are relying more and more on specialized staffs with higher technical skills and drills to control the media appearance of the party and its leader to communicate with the society. In this sense, the access on modern means of communication (and the modern technological presence in general) has influenced not only the size but also the nature of party organization, because stimulates inner specialization and promotes a higher professionalism of the party apparatus. In a period when politics aims to be more and more professionalized, the party structures have the tendency to adapt themselves to these changes. Even though, the access on modern means of communication and technology are important per se, they have gained more relevance in the context of new democracies. Time- or sequence of events- now becomes a critical factor due to the importance of the stages of organizational development in which parties gained access on these means of mass communication and had the chance to use media not only for their campaign but for other activities as well (van Biezen 2003: 41: 42). According to van Biezen the path towards democracy is closely related with the structure and organization of political parties, because it influences their organizational strategies. As a consequence the concepts of path dependency (Mahoney, 1991: 2000: 2001) and the critical junctures (Pierson, 2000: 2004) are intrinsic to explain the structure and party organization in post-communist countries. The order of events is important because it influences and defines what will and how it will happen.

The political parties in the consolidated democracies are characterized by high levels of centralization, increased relevance of professionals and a decreased weight of party activists. Therefore it is observable an increased dominance of the party in public office and a decreased relevance of the extra- parliamentary party. Given that parties in the new democracies were created in an environment in which media was accessible, they gained media access in an earlier stage of their development, even before the development of extra parliamentary organization, and thus they lost the incentives to invest in the territorial organization of the party. As a consequence, the influence of media in the formation of the party organization is more obvious than in Western European countries: media has substituted the need for a territorial penetration of the organization on the ground, and professionals have substituted the need for activists (van Biezen, 42).

Based on a survey conducted by the Institute of Surveys and Opinions in 2002, more than $60 \%$ of the Albanain population above 20's watched television 1-4 hours a day and 25\% watched television for more than 4 hours a day. The same survey showed that round $70 \%$ of people ranked television as the medium that transmits the most reliable information; $55 \%$ said this information was passably reliable and 28\% less reliable (Institute of Surveys and Opinions, Media 2002 in Londo 2006: 2). From the survey we can draw the conclusion that the Albanian population, the electorate sees television as an important mean of information, if not the most important medium, a result that stays in the same line with the literature on political parties and their relationship with the media. Pannebianco (1988) observed that not media in general, but television especially changed the nature of political parties. The printed media has existed before and had accompanied political parties since their creation. That is why we can say that 
the printed media is a feature of mass parties and not a feature of contemporaneous European parties. The press requires a wide distribution network and human resources and that is why the mass party, organized in branches and sub branches, expanded in the whole territory used this medium as the main mechanisms to transmit the party program and ideology. It is exactly the decreased influence of the press and the rise of television that changed the nature of political parties in the West. The OSBE report on election in Albania (2001:11) says:

According to the Institute for Public and Legal Studies, Albania has 13 daily newspapers with a total circulation of approximately 95,000 copies. Due to poor distribution and lack of a subscription system, even those newspapers aspiring to nationwide readership are distributed only in the cities. As in many other countries in transition, Albanians tend to choose TV broadcasts over print news, making it hard for many newspapers to survive.

Due to the impact of the TV on political parties and its importance on the opinion formation in the country, compared with the other media channels, the paper with focus only on the relation between TV and political parties.

The influence that television has exercised on the Albanian political parties is measured first by evaluating the quality of transmission of the Public Television and second, by measuring the territorial coverage of the independent TVs. Preliminarily it could be suggested that in case that the Albanian public television did not offer equal coverage, in terms of time and impartial judgement, for all parties, these parties were more likely to use other means to transmit their information to the electorate and the possible strategy was to create an extensive territorial network, and thus to create a mass party. The second hypothesis is that in case the independent TVs have started to operate in a later phase of party formation, then again the political parties had to find means of message conveyers other than the TV stations. Therefore they had to rely on the traditional 'transmission belts' - the membership. Therefore if the moment of party creation and that of independent TV stations' creation does not coincide, than these lasts ones could not exercise any influence on the structure and organization of the political parties in Albania.

\section{PUBLIC- RADIO TELEVISION AND ALBANIAN POLITICAL PARTIES}

During the transition period, the Albanian media has continued to reflect the same features that characterized her during communism. It found it difficult to emancipate itself and transform from a dependent organ of state-party to an independent institution (Godole, 2014: 70). The stated continued to subsidise quite a high number of media institutions such as TVSH, local public televisions, ATSH (Albanian Telegraphic Agency), Radio Tirana and other local radios in the whole country. In addition to this, the media landscape was enriched by the party press. However, the print media is not part of this study, since the print media is not a variable which could influence the structure of the political parties. Furthermore, it did not have a high legibility due to its entire controlled content by the funding party (Godole, 2014: 70-71). In this context, public media and television especially had the principal role to inform independently the public opinion.

However the reports conducted in that period assess that TVSH has been biased in her stand and has supported publicly the party in government. According to the OSCE report in 1996:

Opposition parties seemed to be consistently banned from holding outdoor meetings, particularly in large towns. In Tirana, opposition parties requested and were denied 
permission for a rally in the central Skanderbeg square, whereas the ruling party was permitted to hold its May 24 rally in the central square. Official explanations ranged from the possibility that opposition parties would not have enough supporters at their rally to justify closing the main square, to the view that the Ruling Party rally was not political but a concert, or to the fact that it was not a political rally but a Presidential address (pg.7).

Under such conditions, it is clear that the opposition parties (the Socialist Party as the main opposition party) had only one mean to let people know their messages and that mean was the Albanian Public Television that was the only source of information that could be spread out in the whole country and who was obliged to report independently. The same OSCE report observes that:

The Society for Democratic Culture, an Albanian non-partisan civic organisation, employed internationally accepted methodology for measuring television time and content during the campaign. The SDC concluded that TV coverage of the parties respected the election law in its allotment of time to the various parties. However the $S D C$ also stated that the extensive coverage afforded to the President and the government represented overwhelming de facto coverage and promotion of the Democratic Party. They also noted that the method of coverage of the DP was also likely to favour them. The SDC cited concern with the order that news reports were presented, and the tendency to allow representatives from the ruling party to read their own statements rather than using a journalist (pg.8-9).

With the fall of communism in 1999, the Albanian Radio Television and ATSH were controlled by the state, more specifically by the Parliament and its majority. In this way, these institutions were in favour of government and here lied the source of the permanent conflict among the newspapers, which were in majority, and the Radio-Television. It looks like the state and the opposition, till 1997, had divided the signs of communication between them: the image and the sound in function of the government and the word in service of the opposition. Till 22 March 1992, a time when the Party of Labour of Albania controlled the Parliament, the presidency and the government, the opposition newspapers attacked the Albanian Radio Television as an instrument of manipulation of public opinion and as a centre of propaganda in favour of the party in power. After the 22nd of March, we have the same situation only that the Socialist Party was now in opposition and the Democratic Party in power. The control that the power exercised on television and its program content continued to be the same. Radio television was considered by the opposition as a manipulative instrument of public opinion, a mean of propaganda in the hands of the power that controlled the state (Fuga, 2008: 434-435). In this context, the opposition parties could not rely on the public television to transmit their messages. They needed to do this through a large organizational network in the whole territory.

\section{MEDIA IN ALBANIA: THE ROLE OF PRIVATE MEDIA}

As discussed above the public television was not the best mean to spread out the messages of political leaders of the Albanian opposition parties. As it is shown by international organisations and media community, the television was controlled by the party in power and that is why the news and political programs were often accused for being biased and in favour of the party in power. Therefore, the private media is seen as an alternative mean of message distribution for the opposition parties. In this sense it is important to know when did the private and independent media started to act in Albania. Does this moment coincides with the 
creation of political parties? The argument of van Biezen (2003) is that political parties in newly established democracies had media access since the moment of their inception and consequently the necessity to organize territorially, as a mass party, did not appear. However the question is whether the same could be applied in the Albanian scene or not? In this context is important to analyse the moment when private televisions appeared and the accessibility of the electorate in their signal.

Until 1995, for the majority of Albanians, electronic media was all about state television. The situation started to change when the first private stations in Albania started to broadcast in 1995. The first private television in Albania, Shijak TV, started its broadcasting on 25th December 1995 even though the law on "Electronic Media" was approved on 30th of September 1998 and ratified on 4th October 1998. According to this law, TVSH became public. Later on were created and licensed a high number of private televisions (Godole, 2014: 78). Based on official data taken by AMA (Authority of Audiovisual Media) of 2006, Albania listed 66 local televisions, two national televisions, and two satellite televisions and 40 Cable TV (in Londo, 2006: 2-3). The majority of electronic media was focused in the western part of the country and especially in Tirana, where are located around $72 \%$ of all radio phonic stations and $75 \%$ of all television stations.

Godele calls this stage as the media consolidation stage. The media sphere during 1998- 2005, especially after 2005 was characterized by nn increase in the number of audio visual mediums such as TV NEWS 24, TV Vision +, ABC News, TV Albanian Screen (previously TV Alsat) etc (Godole, 2014: 79). According to a report by the Council of Europe, 1999, Albania had 30 private TV stations and 30 private radios actively broadcasting. In these conditions it was necessary to draft a law on media that guaranteed the editorial independence and led towards an impartial broadcasting system (Council of Europe, 2000: 9-10). However, in addition to the existence of the independent media itself, it is necessary to know whether such media covered the whole territory or not, since their existence is seen in the light of the ability to spread the message of political parties' leaders throughout the country. The high number of televisions and private radios does not guarantee that they covered the whole territory and that they were capable to broadcast in the whole country. The following table reveals some data about media coverage in Albania:

Table: The territorial coverage with national radio and television broadcaster signal

\begin{tabular}{|l|l|l|l|l|}
\hline \multirow{2}{*}{ I } & \multirow{2}{*}{ Name } & TVSH & TV Klan & TV Top Channel \\
\cline { 2 - 5 } & & Public & Lic. Year 2001 & Lic. Year 2008 \\
\hline \multirow{4}{*}{2002} & Licensing year or re- lic. & ----- & 2 & ----- \\
\cline { 2 - 5 } & Conditions of license & ---- & 7.33 & ------ \\
\cline { 2 - 5 } & Factual coverage \% & 73.31 & 40.91 & ----- \\
\hline \multirow{3}{*}{2003} & Licensing year or re- lic. & ----- & 3 & ------ \\
\cline { 2 - 5 } & Conditions of license & ------- & 26.4 & ------ \\
\cline { 2 - 5 } & Factual coverage \% & 73.31 & 2.68 & ----- \\
\hline \multirow{3}{*}{2005} & Licensing year or re- lic. & ------ & 4 & ----- \\
\cline { 2 - 5 } & Conditions of license & ----- & 46.97 & ----- \\
\cline { 2 - 5 } & Factual coverage \% & 73.31 & 42.68 & ------ \\
\hline \multirow{3}{*}{2006} & Licensing year or re- lic. & ----- & 5 & ----- \\
\cline { 2 - 5 } & Conditions of license & ------- & 46.97 & ----- \\
\cline { 2 - 5 } & Factual coverage \% & 73.31 & 42.68 & ----- \\
\hline & Licensing year or re- lic. & ----- & 6 & ----- \\
\cline { 2 - 5 } & Conditions of license & ---- & 62.09 & \\
\cline { 2 - 5 } & Factual coverage \% & 73.31 & 42.68 & \\
\hline
\end{tabular}




\begin{tabular}{|c|c|c|c|c|}
\hline \multirow{3}{*}{2007} & Licensing year or re- lic. & ----- & 7 & ----- \\
\hline & Conditions of license & ----- & 86.86 & ----- \\
\hline & Factual coverage $\%$ & 73.31 & 44.53 & $\begin{array}{ll}---- \\
--\end{array}$ \\
\hline \multirow{3}{*}{2008} & Licensing year or re- lic. & ---- & 8 & 1 \\
\hline & Conditions of license & ----- & 90 & 50 \\
\hline & Factual coverage $\%$ & 73.31 & 69.8 & 62.1 \\
\hline \multirow{3}{*}{2009} & Licensing year or re- lic. & $\begin{array}{ll}---- \\
\end{array}$ & 1 & 2 \\
\hline & Conditions of license & $\begin{array}{ll}---- \\
\end{array}$ & 90 & 50 \\
\hline & Factual coverage $\%$ & 73.31 & 70.2 & 62.1 \\
\hline \multirow{3}{*}{2010} & Licensing year or re- lic. & $\begin{array}{ll}---- \\
\end{array}$ & 2 & 3 \\
\hline & Conditions of license & ----- & 90 & 90 \\
\hline & Factual coverage \% & 73.31 & 70.2 & 62.1 \\
\hline \multirow{3}{*}{2011} & Licensing year or re- lic. & ----- & 3 & 4 \\
\hline & Conditions of license & ----- & 90 & 90 \\
\hline & Factual coverage $\%$ & 75 & 78 & 79.4 \\
\hline \multirow{3}{*}{2012} & Licensing year or re- lic. & $\begin{array}{ll}---- \\
--\end{array}$ & 4 & 5 \\
\hline & Conditions of license & ----- & 90 & 90 \\
\hline & Factual coverage $\%$ & 87 & 78 & 79 \\
\hline
\end{tabular}

Source: Annual Report 2012 of AMA (pp.57-58).

As one may observe,despite their earlier activity, only in 2008, the two national private channels managed to cover more than 50\% of the territory. In 2011 they achieve the highest percentages: TV Klan covers more than $78 \%$ of the territory while Top Channel $79.4 \%$. According to AMA, TV Klan has decided broadcasting signals in 33 points that cover the Albanian territory and sustained by its satellite platform, and in the terrestrial network "Digitalb", it covers almost the whole territory in the republic of Albania (2012: 58). Same stands true for Top Channel as well (AMA, 2012: 61-62)

Under such conditions the private televisions, Top Channel and Tv Klan gain a special importance in transmitting the political parties messages. They cover the majority of the territory at a time when other local private televisions do not have a good broadcasting quality, are not always broadcasting and fail to cover the areas they are licensed for (AMA, 2012)

However private televisions in Albania appeared long after the creation of Albanian political parties and when they appeared they were concentrated in the central part of the country, covering a small territory and it was impossible for parties to rely on these mediums to transmit their messages to their members and potential electorate.

Therefore it could be concluded that due to state TV broadcasting bias in favour of the party in power and the appearance of private impartial television long after the creation of political parties in Albania, these parties could not rely on them to rich the electorate and continued to use the territorial organizational network. For this reason the contention of van Biezen (2003) does not stand true in the case of Albania, because media cannot act as a influencing factor in the structure of its political parties

\section{CONCLUSION}

The aim of this paper was to explore the connection between political parties and media. The literature on political parties suggests that political parties in Western Europe, in the moment of their foundation, were obliged to adopt an organizational structure that relied on membership that played the role of "transmission belt" to distribute the party messages in the whole country. With the appearance of electronic media, membership lost its relevance, 
because now party leaders could communicate with the electorate through the television and as a result the party typology changed from mass parties into electoral- professional parties.

In terms of organizational structure of political parties in the post-communist countries, the organizational sequence plays a significant role. The literature suggests that because postcommunist political parties were created in an era where access to media was available, it was not necessary to invest on organizational structures of the party. The TV have substituted the member' role as 'transmission belts' in terms of message distribution from the centre to the periphery.

However, the analysis conducted on electronic media influence in Albania, reveals that due to broadcasting bias of Albanian public television in favour of the party in government and the later appearance of private televisions in the end of the 90's, long after their creation, political parties in Albania could not rely on media to arrive at their electorate and therefore, had to use the organizational network on the ground. So the argument of van Biezen (2003) does not stand true for the Albanian reality, because media didn't play any significant role in the structure of Albanian political parties. On the contrary, the Albanian political parties had to rely on an extended organizational network to convey the message from the centre to the periphery. In this context, at the moment of their inception the Albanian political parties display more features of mass parties rather than features of catch all or electoral-professional parties.

\section{References}

AMA (2012) Raporti Vjetor (Annual Report), AMA: Tirane.

Bielasiak, J. (2002) 'The institutionalization of electoral and party systmes in postcommunist states'. Comparative Politics, Vol. 34, fq.189-210.

Duverger, M. (1954) Political Parties: Their Organization and Activities in the Modern State. London: Methuen.

Farrell, David M. and Paul Webb (2000) 'Political Parties as Campaign Organizations', in Russell J. Dalton and Martin P. Wattenberg (eds) Political Change in Advanced Industrial Democracies, Oxford University Press.

Godole, J. (2014) 'Marrëdhëniet jo formale mes elitave të politikës dhe mediave', Doctoral Thesis defended at Tirana State University. Available on: http://www.doktoratura.unitir.edu.al/wpcontent/uploads/2014/02/Doktoratura-Jonila-Godole-Fakulteti-i-Histori-Filologjise-Departamenti-iGazetarise.pdf

Katz R.S., Mair, P. (1995) 'Changing Models of Party Organization and Party Democracy: The Emergence of the Cartel Party', Party Politics, Vol.1 (1), pp.5-28.

Kirchheimer, O. (1966) The Transformation of West European Party Systems', in Joseph LaPalombara and Myron Weiner (eds) Political Parties and Political Development, pp. 177-200. Princeton, NJ: Princeton University Press.

Lazarsfeld, P. F., Berelson, B. \& Gaudet, H. (1944). The people's choice: how the voter makes up his mind in a presidential campaign. New York: Columbia University Press.

Londo, I. (2006) Digital Television in Albania: Policies, Development and Public Debate, Albanian Media Institute: Tiranë.

Mahoney, J. (2001) “Path Dependence in Historical Sociology”. Theory and Society, 29: 507-548.

Michels, R. (1962 [1911]) Political Parties: A Sociological Study of the Oligarchical Tendencies of Modern Democracies. New York: The Free Press.

OSCE/Office for Democratic Institutions and Human Rights (1996) Observation of the Parliamentary Elections Held in the Republic of Albania, May 26 and June 2, 1996, Available at:

http://www.osce.org/odihr/elections/albania/13567?download=true

Panebianco, A. (1988) Political Parties: Organisation and Power. Cambridge:Cambridge University Press. 
Pierson, P. (2000) 'Increasing Returns, Path Dependence, and the Study of Politics, American Political Science Review 94: 251-267.

Sartori, G. (1968) 'Political Development and Political Engineering', pp.261-298 in J.D. Montgomer and A.O.Hirschman (eds) Public Policy 17.

Van Biezen, I. (2003) Political Parties in New Democracies - Party organization in Southern and East-Central Europe. Hampshire: Palgrave MacMillan.

Webb, P. \& White, S. (2007) Conceptualizing the Institutionalization and Performance of Political Parties in New Democracies, Oxford Scholarship Online, DOI: 10.1093/acprof:oso/9780199289653.003.0001. 